\title{
Calcification on an X-Ray: an important feature to recognise
}

\author{
Adam Fell, Andrew Smith
}

Department of Trauma and Orthopaedics, Queen Elizabeth the Queen Mother Hospital, East Kent Hospitals University Foundation Trust, Margate, UK

\section{Correspondence to \\ Dr Adam Fell;}

adam.fell2@nhs.net

Accepted 24 June 2020

\section{DESCRIPTION}

A 76-year old man referred to the orthopaedic team at our institution following a fall in garden onto the right knee with swelling and inability to weight bear or straight leg raise with the following radiograph (figure 1) displaying a displaced patellar fracture with diffuse soft tissue calcification of the posterior thigh. Prior medical history included hypertension for which he took the calcium channel blocker and ACE inhibitor; otherwise, he did not visit the General Practitioner for any other complaints. $\mathrm{He}$ was a non-smoker and still was active cycling a few miles most days.

On examination, there was bruising to the right knee with a large effusion, tenderness and inability to straight leg raise or flex. There was a hard nonpulsatile mass felt in the posterior thigh of both the right leg and the left leg. The sensation was intact. No sequel of peripheral vascular disease was seen. Dorsalis pedis, posterior tibial, popliteal and femoral pulses were not palpated bilaterally with no pulsatile masses felt in the abdomen. On further questioning, he admitted decreasing exercise tolerance and history of intermittent claudication at 200 yards and worsening proprioception in the lower limbs having a number of falls.

The patient was discussed with the vascular team who recommended computer tomography angiogram of the lower limbs performed due to the concern over the popliteal aneurysm. This displayed multiple fusiform aneurysms from aortic, common iliac arteries, common femoral arteries aneurysms and both popliteal arteries (figure 2). There was absent flow distal to the popliteal vessels but evidence of distal perfusion via collateral vessels (figure 3 ). The patient underwent open reduction and internal fixation with tension band wire without tourniquet due to the risk of rupture of the aneurysm and acute ischaemia to the right lower limb. The procedure was performed without complication and the patient was discharged 3 days later. The patient was reviewed by the vascular team and was worked up for bilateral iliac aneurysm repair with a custom endovascular graft due to the widespread complex aneurysmal disease.

This case highlights the importance of recognising abnormal calcification on radiographs and creating a differential for it and performing an appropriate vascular examination to identify possible aneurysms. The incidence of the isolated popliteal aneurysmal disease is uncommon with studies showing around $1 \%{ }^{1}$ It is the most common peripheral aneurysm and is associated with aortic aneurysm $40 \%-50 \%$ of the time. ${ }^{1}$ Complex multilevel aneurysmaldiseaseasseeninthispatientisrareat $<1 \%{ }^{2}$

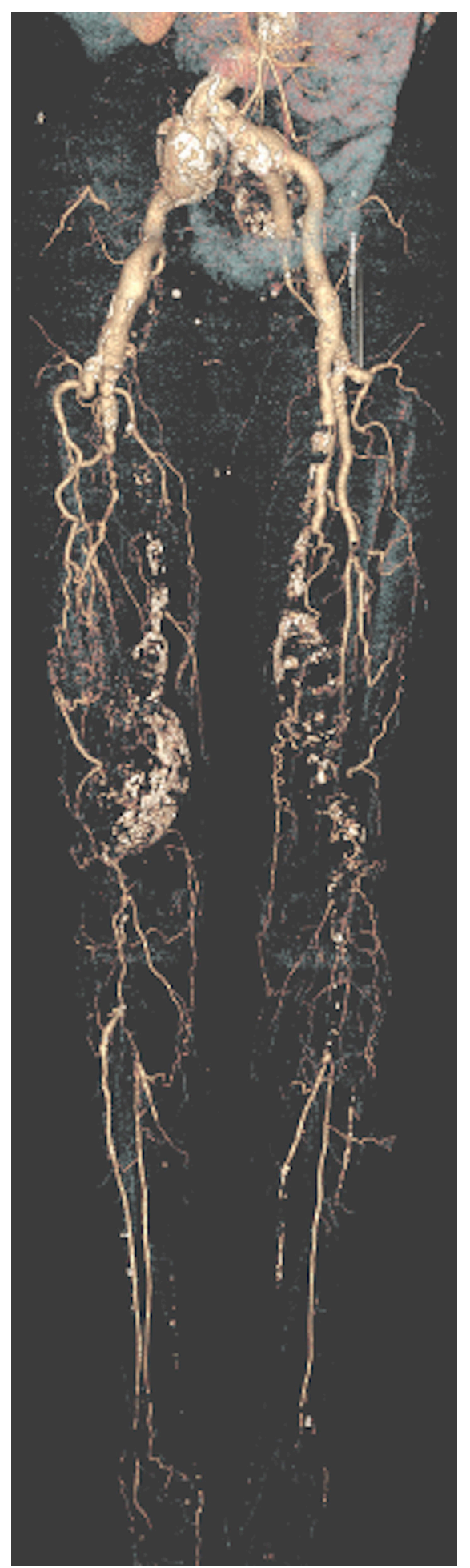

Figure 1 Angiogram reconstruction profile of patients CT angiogram, showing diffuse atherosclerotic disease with no through popliteal vessels bilaterally 


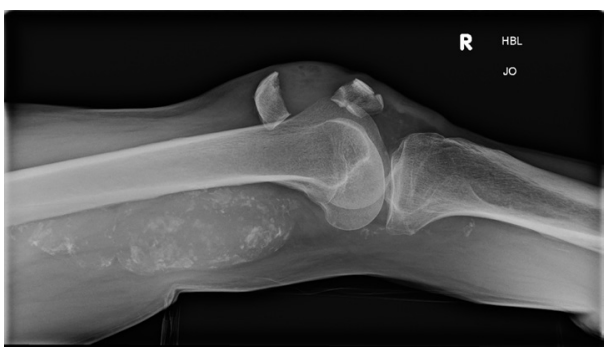

Figure 2 Lateral radiograph of the right knee showing popliteal vessel calcification and displaced the right patellar fracture.

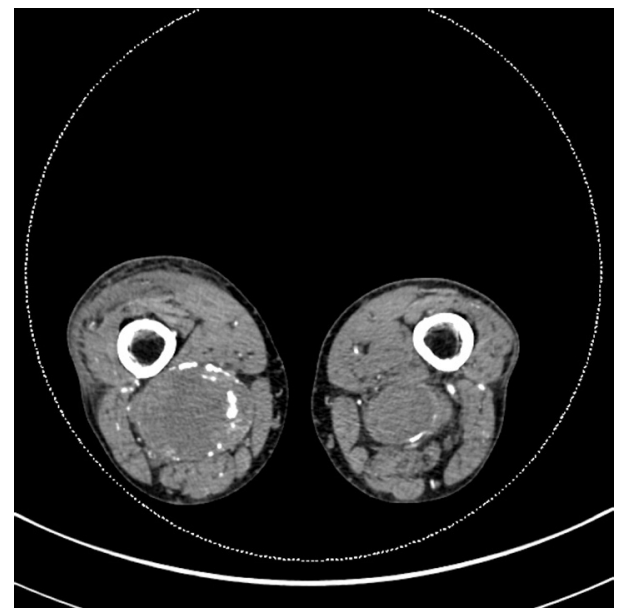

Figure $3 \mathrm{Ct}$ angiogram showing bilateral popliteal artery aneurysms. The left popliteal aneurysm measuring $3.2 \mathrm{~cm}$ and the Right popliteal aneurysm measuring and the right popliteal aneurysm measuring 6.3
Learning points

- Lower limb aneurysmal disease can present in many ways and is typically seen in male patients with cardiovascular risk factors.

- Recognising abnormal calcifications on radiograph and performing full vascular examination in a patient with cardiovascular risk factors is important and carrying out appropriate investigations due to the impact on management and treatment of patients with lower limb fractures.

- Referral to vascular service is important due to the complex nature of disease and the high risk of thromboembolic complications in the future from lower limb aneurysmal disease.

Acknowledgements Thank you to the patient for allowing me to publish and to Mr Andrew Smith for supporting this submission.

Contributors AF treated patient from presentation to discharge. AS reviewed article and gave support and guidance.

Funding The authors have not declared a specific grant for this research from any funding agency in the public, commercial or not-for-profit sectors.

Competing interests None declared.

Patient consent for publication Obtained.

Provenance and peer review Not commissioned; externally peer reviewed.

\section{REFERENCES}

1 Trickett JP, Scott RAP, Tilney HS. Screening and management of asymptomatic popliteal aneurysms. J Med Screen 2002;9:92-3.

2 Diwan A, Sarkar R, Stanley JC, et al. Incidence of femoral and popliteal artery aneurysms in patients with abdominal aortic aneurysms. J Vasc Surg 2000;31:863-9.

$\mathrm{cm}$.

Copyright 2020 BMJ Publishing Group. All rights reserved. For permission to reuse any of this content visit

https://www.bmj.com/company/products-services/rights-and-licensing/permissions/

BMJ Case Report Fellows may re-use this article for personal use and teaching without any further permission.

Become a Fellow of BMJ Case Reports today and you can:

- Submit as many cases as you like

- Enjoy fast sympathetic peer review and rapid publication of accepted articles

- Access all the published articles

- Re-use any of the published material for personal use and teaching without further permission

Customer Service

If you have any further queries about your subscription, please contact our customer services team on +44 (0) 2071111105 or via email at support@bmj.com.

Visit casereports.bmj.com for more articles like this and to become a Fellow 